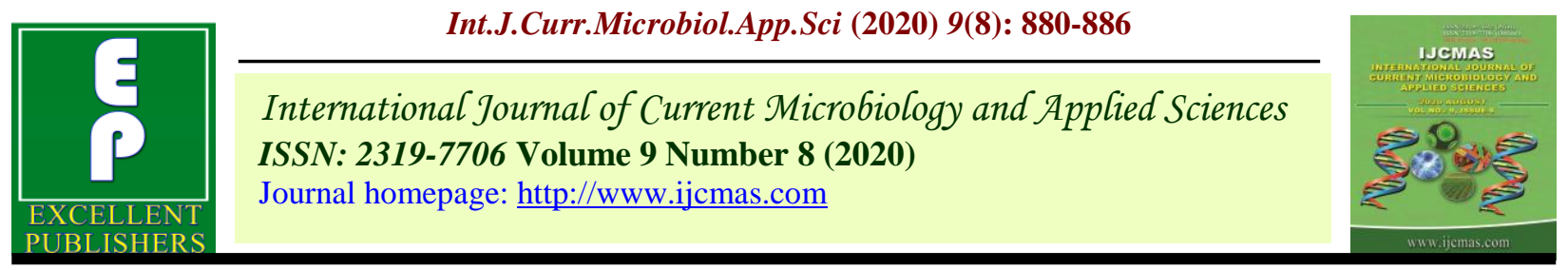

\title{
Effect of Milling Methods on the Infestation of Sitophilus oryzae (L.) (Coleoptera: Curculionidae) on Stored Rice Grains in Terai Agro-Ecology of West Bengal
}

\author{
Supriya Okram* and T. K. Hath \\ Department of Agricultural Entomology, Uttar Banga Krishi Vishwavidyalaya, \\ UBKV, Pundibari, West Bengal, India \\ *Corresponding author
}

\begin{abstract}
A B S T R A C T
Laboratory experiments were carried out to study the effect of milling methods on the infestation of Sitophilus oryzae on stored rice grains during 2016-17. The results of the

Keywords

Sitophilus oryzae,

Rice, Milling

methods, Iron

milling, Rubber

milling

Article Info

Accepted:

10 July 2020

Available Online:

10 August 2020 present investigation reveals that rubber milled rice were more preferred by the weevils than the iron milled rice with significant differences in weight loss existing among the various rice categories and the highest weight loss per cent was registered from SBA rice category $(31.26 \pm 0.60$ and $33.07 \pm 0.62)$ and the lowest from SMNA rice category (24.47 \pm 0.55 and $25.98 \pm 0.56)$ in 2016 and 2017 respectively. The highest damaged grain percentage was also registered from SBA rice category with $42.58 \pm 0.48 \%$ and $41.22 \pm 0.42 \%$ in 2016 and 2017 respectively. The two milling method also had notable impact on the adult population of $S$. oryzae produced from the stored grain at 90 DAS. It was observed that the adult population from rubber milled rice was significantly higher (330.17 \pm 5.31 and $340.50 \pm 5.44)$ than the population recorded from the iron milled rice (264.18 \pm 5.31 and $274.74 \pm 5.44$ ) in both the experimental years of studies i.e., 2016 and 2017. The carbohydrates and protein content so obtained from the present studies were also noted to be one of the main factors to contribute to the preference of the rice weevils in which rubber milled rice (having $55.55 \pm 0.67 \%$ and $11.05 \pm 0.15 \%$ carbohydrate and protein respectively) had greater quantity of these as compared to the iron milled rice ( $49.74 \pm 0.67 \%$ and $9.09 \pm 0.15 \%$ carbohydrate and protein respectively).
\end{abstract}

\section{Introduction}

Rice, Oryza sativa (Linn.) is an economically important crop and the most important staple foods for the world's population. More than $90 \%$ of the world's rice is produced and consumed in Asia. The rice grain consists of $75-80 \%$ starch, $12 \%$ water and only $7 \%$ protein with a full complement of amino acids. Its protein is highly digestible with excellent biological values and protein efficiency ratio owing to the presence of higher concentration ( $4 \%$ ) of lysine (Oko et al., 2012). The process of removal of hulls and brans from paddy grains to produce polished rice is termed as the rice milling. The effect of the milling process on the outcome of rice quality has been researched by examining the quality of the whitened rice product focusing on parameters such as degree of milling, transparency, whitening, and yield (Schramm, 2006). The brown rice 
contains more protein, minerals, and vitamins as compared to the milled rice or the white rice (Jones et al., 1946). FAO (1954) reported that the milled or white rice is more attractive in appearance, requires less time to cook, and keeps better in storage than the brown rice but in humid environments both easily become rancid. It was observed that the protein content of rough, brown, and milled rice varied significantly among varieties where the Asian rice varieties were generally of lower protein content than those varieties planted in the United States and also difference of about $4 \%$ in protein content of the same variety of rice planted at different seasons was observed Juliano et al., (1964). Both the white and brown rice are susceptible to the rice weevil, $S$. oryzae as the adults feed on rice and the larva develops inside the rice kernel (Arbogast, 1991 and Beckett et al., 1994).

\section{Materials and Methods}

The study was conducted in the Department of Agricultural Entomology of the varsity located at Pundibari, Coochbehar, West Bengal (India) during 2016 and 2017. For conducting this experiment all the paddy germplasms were milled by adopting different milling methods viz., iron milling and the another method by using the rubber huller namely "Palm Husker".

The rice grains thus obtained after milling were sterilized under UV rays for 30 minutes in order to kill all existing insects or eggs or pathogens. After the sterilization, grains of each germplasm weighing $50 \mathrm{gm}$ containing only the sound, unaffected grains were kept in plastic bottle of $250 \mathrm{gm}$ capacity. Later ten pairs (male female ratio of 1:1) of five days old weevils were introduced in each bottle and tops were kept covered with muslin cloth and tightly fixed with rubber band to provide proper aeration. The observations on different parameters viz., percent of damage grains and grain weight loss to different germplasms by rice weevil were taken up to 90 days at weekly intervals. The population build up of the adult weevil was also recorded after 90 days of storage. Different physiological parameters like moisture percentage, length, breadth, 1000 grain weight, 100 grain volume and 100 grain density of the rice grains of each of the germplasm were also determined. Likewise the biochemical parameters viz., proteins and carbohydrates were also determined.

\section{Results and Discussion}

The present studies were to see the effects of milling methods of rice on the infestation of Sitophilus oryzae (L.) where two milling methods were adopted. Firstly, iron milling in which all or part of the bran and germ from the rough rice/paddy was removed and the milled rice so obtained are also called as white rice. And secondly the rubber milling by using the palm husker where the least processed form of rice was done by removing only the outer hull but the bran layers and the germ still retains and the rice produced from this milling method is also called as brown rice.

However, both white and brown rice are susceptible to the rice weevil as the adults feed on rice and the larva develops inside the rice kernel (Arbogast, 1991; Beckett et al., 1994). As per Poonam Dhankhar (2004) milling is a crucial step in post-production of rice where the basic objective is to remove the husk and the bran layers from paddy grains and to produce polished rice which is edible and white rice kernel free of impurities.

The rice produced from these two different milling methods greatly influenced the infestation level of Sitophilus oryzae and the results of the present investigation reveals that irrespective of the rice categories rubber milled rice was more preferred by the weevils to the iron milled rice in both the years of studies as shown in table numbers 1, 2 and 3. 
Table.1 Impact of milling methods on the percentage of grain weight loss of different rice categories due to $S$. oryzae in summer and winter season during 2016 and 2017

\begin{tabular}{|c|c|c|c|c|c|c|c|}
\hline \multirow{2}{*}{\multicolumn{2}{|c|}{ Categories }} & \multicolumn{3}{|c|}{2016} & \multicolumn{3}{|c|}{2017} \\
\hline & & Summer & Winter & Pooled & Summer & Winter & Pooled \\
\hline \multicolumn{2}{|c|}{ Medium aromatic } & $(34.00 \pm 1.59) \mathrm{ab}$ & $(25.15 \pm 2.18) a b$ & $(29.58 \pm 1.35) \mathrm{ab}$ & $(36.17 \pm 1.66) a b$ & $(26.22 \pm 2.20) \mathrm{ab}$ & $(31.19 \pm 1.38) a b$ \\
\hline \multicolumn{2}{|c|}{$\begin{array}{l}\text { Medium non } \\
\text { aromatic }\end{array}$} & $(32.95 \pm 0.71) \mathrm{ab}$ & $(23.21 \pm 0.98) \mathrm{ab}$ & $(28.08 \pm 0.60) b c$ & $(35.06 \pm 0.74) \mathrm{ab}$ & $(24.56 \pm 0.99) a b$ & $(29.81 \pm 0.62) b c$ \\
\hline \multicolumn{2}{|c|}{$\begin{array}{l}\text { Short bold } \\
\text { aromatic }\end{array}$} & $(35.66 \pm 0.71) \mathrm{a}$ & $(26.85 \pm 0.98) a$ & $(31.26 \pm 0.60) \mathrm{a}$ & $(37.92 \pm 0.74) \mathrm{a}$ & $(28.22 \pm 0.99) \mathrm{a}$ & $(33.07 \pm 0.62) a$ \\
\hline \multicolumn{2}{|c|}{$\begin{array}{l}\text { Short bold non } \\
\text { aromatic }\end{array}$} & $(34.24 \pm 0.75) \mathrm{ab}$ & $(25.29 \pm 1.03) \mathrm{ab}$ & $(29.77 \pm 0.64) a b$ & $(36.33 \pm 0.78) a b$ & $(26.52 \pm 1.04) \mathrm{ab}$ & $(31.42 \pm 0.65) \mathrm{ab}$ \\
\hline \multicolumn{2}{|c|}{$\begin{array}{l}\text { Short medium } \\
\text { aromatic }\end{array}$} & $(31.58 \pm 0.85) b c$ & $(21.69 \pm 1.17) b c$ & $(26.63 \pm 0.72) \mathrm{cd}$ & $(33.48 \pm 0.89) b c$ & $(22.77 \pm 1.18) b c$ & $(28.13 \pm 0.74) \mathrm{cd}$ \\
\hline \multicolumn{2}{|c|}{$\begin{array}{l}\text { Short medium } \\
\text { non aromatic }\end{array}$} & $(29.69 \pm 0.65) \mathrm{c}$ & $(19.24 \pm 0.89) \mathrm{c}$ & $(24.47 \pm 0.55) \mathrm{d}$ & $(31.60 \pm 0.68) \mathrm{c}$ & $(20.36 \pm 0.90) c$ & $(25.98 \pm 0.56) d$ \\
\hline \multicolumn{2}{|c|}{ Probability } & $<0.001$ & $<0.001$ & $<0.001$ & $<0.001$ & $<0.001$ & $<0.001$ \\
\hline \multirow[t]{2}{*}{ Milling } & Iron & $29.32 \pm 0.54$ & $21.40 \pm 0.74$ & $25.36 \pm 0.46$ & $30.87 \pm 0.56$ & $22.52 \pm 0.75$ & $26.70 \pm 0.47$ \\
\hline & Rubber & $36.72 \pm 0.54$ & $25.74 \pm 0.74$ & $31.23 \pm 0.46$ & $39.32 \pm 0.56$ & $27.03 \pm 0.75$ & $33.17 \pm 0.47$ \\
\hline \multicolumn{2}{|c|}{ Probability } & $<0.001$ & $<0.001$ & $<0.001$ & $<0.001$ & $<0.001$ & $<0.001$ \\
\hline \multicolumn{2}{|c|}{ CV $(\%)$} & 9.62 & 18.50 & 13.48 & 9.47 & 17.79 & 13.04 \\
\hline
\end{tabular}

Table.2 Impact of milling methods on the percentage of damaged grains of different rice categories due to S. oryzae in summer and winter season during 2016 and 2017

\begin{tabular}{|c|c|c|c|c|c|c|c|}
\hline \multirow{2}{*}{\multicolumn{2}{|c|}{ Categories }} & \multicolumn{3}{|c|}{2016} & \multicolumn{3}{|c|}{2017} \\
\hline & & Summer & Winter & Pooled & Summer & Winter & Pooled \\
\hline \multicolumn{2}{|c|}{$\begin{array}{l}\text { Medium } \\
\text { aromatic }\end{array}$} & $(48.42 \pm 1.42) \mathrm{ab}$ & $(29.91 \pm 1.51) \mathrm{ab}$ & $(39.16 \pm 1.04) b$ & $(50.27 \pm 1.49) \mathrm{ab}$ & $(30.71 \pm 1.52) \mathrm{ab}$ & $(40.49 \pm 1.07) b$ \\
\hline \multicolumn{2}{|c|}{$\begin{array}{l}\text { Medium non } \\
\text { aromatic }\end{array}$} & $(47.40 \pm 0.63) \mathrm{bc}$ & $(29.32 \pm 0.68) b$ & $(38.36 \pm 0.46 b) c$ & $(49.13 \pm 0.67) b c$ & $(30.15 \pm 0.68) b$ & $(39.64 \pm 0.48) b c$ \\
\hline \multicolumn{2}{|c|}{$\begin{array}{l}\text { Short bold } \\
\text { aromatic }\end{array}$} & $(50.16 \pm 0.63) \mathrm{a}$ & $(32.28 \pm 0.68) a$ & $(41.22 \pm 0.46) \mathrm{a}$ & $(52.03 \pm 0.67) \mathrm{a}$ & $(33.14 \pm 0.68) \mathrm{a}$ & $(42.58 \pm 0.48) \mathrm{a}$ \\
\hline \multicolumn{2}{|c|}{$\begin{array}{l}\text { Short bold non } \\
\text { aromatic }\end{array}$} & $(48.52 \pm 0.67) a b$ & $(29.71 \pm 0.71) a b$ & $(39.12 \pm 0.49) b$ & $(50.31 \pm 0.70) \mathrm{ab}$ & $(30.52 \pm 0.72) a b$ & $(40.42 \pm 0.50) b$ \\
\hline \multicolumn{2}{|c|}{$\begin{array}{l}\text { Short medium } \\
\text { aromatic }\end{array}$} & $(45.92 \pm 0.76) \mathrm{cd}$ & $(27.55 \pm 0.81) \mathrm{bc}$ & $(36.73 \pm 0.55) \mathrm{cd}$ & $(47.60 \pm 0.80) \mathrm{cd}$ & $(28.34 \pm 0.81) b c$ & $(37.97 \pm 0.57) \mathrm{cd}$ \\
\hline \multicolumn{2}{|c|}{$\begin{array}{l}\text { Short medium } \\
\text { non aromatic }\end{array}$} & $(44.60 \pm 0.58) d$ & $(26.44 \pm 0.62) c$ & $(35.52 \pm 0.42) \mathrm{d}$ & $(46.11 \pm 0.61) \mathrm{d}$ & $(27.25 \pm 0.62) \mathrm{c}$ & $(36.68 \pm 0.44) \mathrm{d}$ \\
\hline \multicolumn{2}{|c|}{ Probability } & $<0.001$ & $<0.001$ & $<0.001$ & $<0.001$ & $<0.001$ & $<0.001$ \\
\hline \multirow[t]{2}{*}{ Milling } & Iron & $46.64 \pm 0.48$ & $23.76 \pm 0.51$ & $35.20 \pm 0.35$ & $48.06 \pm 0.51$ & $24.79 \pm 0.52$ & $36.42 \pm 0.36$ \\
\hline & Rubber & $48.36 \pm 0.48$ & $34.65 \pm 0.51$ & $41.50 \pm 0.35$ & $50.43 \pm 0.51$ & $35.25 \pm 0.52$ & $42.84 \pm 0.36$ \\
\hline \multicolumn{2}{|c|}{ Probability } & .013 & $<0.001$ & $<0.001$ & 0.001 & $<0.001$ & $<0.001$ \\
\hline \multicolumn{2}{|c|}{ CV (\%) } & 5.97 & 10.34 & 7.64 & 6.07 & 10.15 & 7.62 \\
\hline
\end{tabular}


Table.3 Impact of milling methods on the adult population of Sitophilus oryzae after 90days of storage in summer and winter season during 2016 and 2017

\begin{tabular}{|c|c|c|c|c|c|c|c|}
\hline \multirow{2}{*}{\multicolumn{2}{|c|}{ Categories }} & \multicolumn{3}{|c|}{2016} & \multicolumn{3}{|c|}{2017} \\
\hline & & Summer & Winter & Pooled & Summer & Winter & Pooled \\
\hline \multicolumn{2}{|c|}{ Medium aromatic } & $(382.75 \pm 19.57) a$ & $(253.83 \pm 24.37) \mathrm{a}$ & $(318.29 \pm 15.63) \mathrm{ab}$ & $(393.83 \pm 20.34) \mathrm{a}$ & $(263.17 \pm 24.74) \mathrm{a}$ & $(328.50 \pm 16.02) a b$ \\
\hline \multicolumn{2}{|c|}{ Medium non aromatic } & $(363.85 \pm 8.75) \mathrm{ab}$ & $(230.47 \pm 10.90) \mathrm{ab}$ & $(297.16 \pm 6.99) b$ & $(376.27 \pm 9.10) \mathrm{ab}$ & $(239.48 \pm 11.06) \mathrm{ab}$ & $(307.87 \pm 7.16) b$ \\
\hline \multicolumn{2}{|c|}{ Short bold aromatic } & $(396.38 \pm 8.75) \mathrm{a}$ & $(271.03 \pm 10.90) \mathrm{a}$ & $(333.71 \pm 6.99) a$ & $(409.73 \pm 9.10) \mathrm{a}$ & $(281.17 \pm 11.06) \mathrm{a}$ & $(345.45 \pm 7.16) a$ \\
\hline \multicolumn{2}{|c|}{ Short bold non aromatic } & $(382.13 \pm 9.22) \mathrm{a}$ & $(249.98 \pm 11.49) \mathrm{a}$ & $(316.06 \pm 7.37) a b$ & $(394.00 \pm 9.59) a$ & $(259.63 \pm 11.66) \mathrm{a}$ & $(326.82 \pm 7.55) \mathrm{ab}$ \\
\hline \multicolumn{2}{|c|}{ Short medium aromatic } & $(345.22 \pm 10.46) b c$ & $(196.93 \pm 13.03) b c$ & $(271.07 \pm 8.35) \mathrm{c}$ & $(355.69 \pm 10.87) b c$ & $(205.79 \pm 13.23) b c$ & $(280.74 \pm 8.56) c$ \\
\hline \multicolumn{2}{|c|}{ Short medium non aromatic } & $(321.64 \pm 7.99) \mathrm{c}$ & $(171.93 \pm 9.95) \mathrm{c}$ & $(246.79 \pm 6.38) \mathrm{c}$ & $(331.61 \pm 8.30 c$ & $(181.06 \pm 10.10) \mathrm{c}$ & $(256.33 \pm 6.54) \mathrm{c}$ \\
\hline \multicolumn{2}{|c|}{ Probability } & $<0.001$ & $<0.001$ & $<0.001$ & $<0.001$ & $<0.001$ & $<0.001$ \\
\hline \multirow[t]{2}{*}{ Milling } & Iron & $326.62 \pm 6.64$ & $201.75 \pm 8.27$ & $264.18 \pm 5.31$ & $337.53 \pm 6.91$ & $211.95 \pm 8.40$ & $274.74 \pm 5.44$ \\
\hline & Rubber & $404.04 \pm 6.64$ & $256.31 \pm 8.27$ & $330.17 \pm 5.31$ & $416.18 \pm 6.91$ & $264.81 \pm 8.40$ & $340.50 \pm 5.44$ \\
\hline \multicolumn{2}{|c|}{ Probability } & $<0.001$ & $<0.001$ & $<0.001$ & $<0.001$ & $<0.001$ & $<0.001$ \\
\hline \multicolumn{2}{|l|}{ CV (\%) } & 10.71 & 21.28 & 14.87 & 10.80 & 20.76 & 14.73 \\
\hline
\end{tabular}

Table.4 Bio chemical parameters of different rice categories during 2016 and 2017 (pooled)

\begin{tabular}{|c|c|c|c|c|c|c|c|}
\hline \multirow{2}{*}{\multicolumn{2}{|c|}{ Categories }} & \multicolumn{3}{|c|}{ Carbohydrate content $(\%)$} & \multicolumn{3}{|c|}{ Protein content (\%) } \\
\hline & & 2016 & 2017 & Pooled & 2016 & 2017 & Pooled \\
\hline \multicolumn{2}{|c|}{ Medium aromatic } & $(55.36 \pm 2.81) \mathrm{a}$ & $(55.38 \pm 2.79) \mathrm{a}$ & $(55.37 \pm 1.98) \mathrm{ab}$ & $(10.24 \pm 0.62) \mathrm{a}$ & $(10.94 \pm 0.64) a b$ & $(10.59 \pm 0.44) \mathrm{a}$ \\
\hline \multicolumn{2}{|c|}{ Medium non aromatic } & $(52.95 \pm 1.26) \mathrm{ab}$ & $(52.99 \pm 1.25) \mathrm{ab}$ & $(52.97 \pm 0.89) \mathrm{b}$ & $(9.83 \pm 0.28) \mathrm{ab}$ & $(10.70 \pm 0.28) a b$ & $(10.26 \pm 0.20) a b$ \\
\hline \multicolumn{2}{|c|}{ Short bold aromatic } & $(57.70 \pm 1.26) \mathrm{a}$ & $(57.79 \pm 1.25) \mathrm{a}$ & $(57.74 \pm 0.89) \mathrm{a}$ & $(9.04 \pm 0.28) b$ & $(9.77 \pm 0.28) b$ & $(9.40 \pm 0.20) c$ \\
\hline \multicolumn{2}{|c|}{ Short bold non aromatic } & $(54.83 \pm 1.32) \mathrm{a}$ & $(54.56 \pm 1.32) \mathrm{a}$ & $(54.70 \pm 0.93) \mathrm{ab}$ & $(9.37 \pm 0.29) a b$ & $(10.22 \pm 0.30) a b$ & $(9.79 \pm 0.21) b c$ \\
\hline \multicolumn{2}{|c|}{ Short medium aromatic } & $(48.49 \pm 1.50) \mathrm{bc}$ & $(48.65 \pm 1.49) \mathrm{bc}$ & $(48.57 \pm 1.06) c$ & $(9.18 \pm 0.33) \mathrm{ab}$ & $(10.11 \pm 0.34) \mathrm{ab}$ & $(9.64 \pm 0.24) b c$ \\
\hline \multicolumn{2}{|c|}{ Short medium non aromatic } & $(46.47 \pm 1.15) \mathrm{c}$ & $(46.54 \pm 1.14) \mathrm{c}$ & $(46.50 \pm 0.81) \mathrm{c}$ & $(10.30 \pm 0.25) \mathrm{a}$ & $(11.10 \pm 0.26) \mathrm{a}$ & $(10.70 \pm 0.18) \mathrm{a}$ \\
\hline \multicolumn{2}{|c|}{ Probability } & $<0.001$ & $<0.001$ & $<0.001$ & 0.011 & 0.016 & $<0.001$ \\
\hline \multirow[t]{2}{*}{ Milling } & Iron & $48.69 \pm 0.95$ & $50.78 \pm 0.95$ & $49.74 \pm 0.67$ & $8.51 \pm 0.21$ & $9.66 \pm 0.22$ & $9.09 \pm 0.15$ \\
\hline & Rubber & $56.57 \pm 0.95$ & $54.52 \pm 0.95$ & $55.55 \pm 0.67$ & $10.81 \pm 0.21$ & $11.28 \pm 0.22$ & $11.05 \pm 0.15$ \\
\hline \multicolumn{2}{|c|}{ Probability } & $<0.001$ & 0.007 & $<0.001$ & $<0.001$ & $<0.001$ & $<0.001$ \\
\hline \multicolumn{2}{|c|}{ CV $(\%)$} & 10.67 & 10.61 & 10.64 & 12.83 & 12.16 & 12.49 \\
\hline
\end{tabular}


Table.5 Physical parameters of different rice categories due to Sitophilus oryzae in during 2016 and 2017 (pooled)

\begin{tabular}{|c|c|c|c|c|c|c|c|c|}
\hline Categories & Moisture (\%) & $\begin{array}{l}\text { Length } \\
(\mathrm{mm})\end{array}$ & Breadth $(\mathbf{m m})$ & \multicolumn{2}{|c|}{ Wt of 100 grains (g) } & Wt of 1000 grains (g) & $\begin{array}{l}\text { Vol of } 100 \\
\text { grains }(\mathrm{cm} 3)\end{array}$ & $\begin{array}{l}\text { Density of } 100 \\
\text { grains }(\mathrm{g} / \mathrm{cm} 3)\end{array}$ \\
\hline $\begin{array}{l}\text { Medium } \\
\text { aromatic }\end{array}$ & $(10.98 \pm 0.21) \mathrm{ab}$ & $(5.66 \pm 0.14) \mathrm{a}$ & $(2.41 \pm 0.08) b c$ & \multicolumn{2}{|c|}{$(1.44 \pm 0.10) b$} & $(14.40 \pm 1.04) b$ & $(1.63 \pm 0.16) b$ & $(0.90 \pm 0.04) \mathrm{b}$ \\
\hline $\begin{array}{l}\text { Medium } \\
\text { non } \\
\text { aromatic }\end{array}$ & $(10.62 \pm 0.09) b c$ & $(5.64 \pm 0.06) \mathrm{a}$ & $(2.30 \pm 0.04) \mathrm{c}$ & \multicolumn{2}{|c|}{$(1.36 \pm 0.05) b c$} & $(13.53 \pm 0.47) b c$ & $(1.57 \pm 0.07) b$ & $(0.89 \pm 0.02) b$ \\
\hline $\begin{array}{l}\text { Short bold } \\
\text { aromatic }\end{array}$ & $(11.24 \pm 0.09) \mathrm{a}$ & $(4.60 \pm 0.06) c$ & $(2.61 \pm 0.04) \mathrm{a}$ & \multicolumn{2}{|c|}{$(1.64 \pm 0.05) \mathrm{a}$} & $(16.33 \pm 0.47) \mathrm{a}$ & $(1.95 \pm 0.07) \mathrm{a}$ & $(0.88 \pm 0.02) \mathrm{b}$ \\
\hline $\begin{array}{l}\text { Short bold } \\
\text { non } \\
\text { aromatic }\end{array}$ & $(10.79 \pm 0.10) b$ & $(4.59 \pm 0.07) \mathrm{c}$ & $(2.54 \pm 0.04) \mathrm{ab}$ & \multicolumn{2}{|c|}{$(1.50 \pm 0.05) \mathrm{ab}$} & $(14.93 \pm 0.49) \mathrm{ab}$ & $(1.73 \pm 0.08) \mathrm{ab}$ & $(0.90 \pm 0.02) \mathrm{b}$ \\
\hline $\begin{array}{l}\text { Short } \\
\text { medium } \\
\text { aromatic }\end{array}$ & $(10.35 \pm 0.11) \mathrm{cd}$ & $(4.95 \pm 0.08) b$ & $(2.08 \pm 0.04) \mathrm{d}$ & \multicolumn{2}{|c|}{$(1.19 \pm 0.06) \mathrm{cd}$} & $(11.88 \pm 0.56) \mathrm{cd}$ & $(1.23 \pm 0.09) \mathrm{c}$ & $(0.99 \pm 0.02) \mathrm{a}$ \\
\hline $\begin{array}{l}\text { Short } \\
\text { medium } \\
\text { non } \\
\text { aromatic }\end{array}$ & $(10.12 \pm 0.09) \mathrm{d}$ & $(4.95 \pm 0.06) b$ & $(2.05 \pm 0.03) \mathrm{d}$ & \multicolumn{2}{|c|}{$(1.08 \pm 0.04) \mathrm{d}$} & $(10.85 \pm 0.42) \mathrm{d}$ & $(1.06 \pm 0.07) \mathrm{c}$ & $(1.04 \pm 0.02) \mathrm{a}$ \\
\hline Probability & $<0.001$ & $<0.001$ & $<0.001$ & \multicolumn{2}{|l|}{$<0.001$} & $<0.001$ & $<0.001$ & $<0.001$ \\
\hline Milling & Iron & $10.76 \pm 0.07$ & $4.95 \pm 0.05$ & $2.30 \pm 0.03$ & $1.33 \pm 0.04$ & $13.31 \pm 0.35$ & $1.41 \pm 0.06$ & $0.98 \pm 0.01$ \\
\hline Rubber & $10.61 \pm 0.07$ & $5.18 \pm 0.05$ & $2.37 \pm 0.03$ & \multicolumn{2}{|c|}{$1.40 \pm 0.04$} & $14.00 \pm 0.35$ & $1.65 \pm 0.06$ & $0.89 \pm 0.01$ \\
\hline Probability & 0.136 & 0.001 & 0.070 & \multicolumn{2}{|c|}{0.169} & 0.174 & 0.003 & $<0.001$ \\
\hline CV (\%) & 5.62 & 7.84 & 10.21 & \multicolumn{2}{|l|}{21.68} & 21.55 & 30.09 & 13.14 \\
\hline
\end{tabular}


The result so obtained lends support from Stejskal and Kucerova (1996) as they stated that Sitophilus spp. prefers larger seeds for oviposition and large seed were more likely to be parasitized or contain more than one egg than smaller seeds and from the present studies the physical parameters of the rubber milled rice $(5.18 \pm 0.05 \mathrm{~mm}, 2.37 \pm 0.03 \mathrm{~mm}$, $1.40 \pm 0.04 \mathrm{~g}, 14.00 \pm 0.35 \mathrm{~g}$ and $1.65 \pm$ $0.06 \mathrm{~cm} 3$ in length, breadth, weight of 100 grains, weight of 1000 grains and volume of 100 grains respectively) was greater than the iron milled rice $(4.95 \pm 0.05 \mathrm{~mm}, 2.30 \pm$ $0.03 \mathrm{~mm}, 1.33 \pm 0.04 \mathrm{~g}, 13.31 \pm 0.35 \mathrm{~g}$ and 1.41 $\pm 0.06 \mathrm{~cm} 3$ in length, breadth, weight of 100 grains, weight of 1000 grains and volume of 100 grains respectively) which was shown in table no. 5. The report of Russell (1968) further corroborates the present results as he observed that weevil preferred to lay in large size grains.

The present findings are also in agreement to the results of Floyd and Newsom (1959) who also stated that $S$. oryzae in feeding preference tests, used to choose unpolished rice, sorghum, maize and wheat in order and they developed more rapidly in sorghum and unpolished rice than in maize. The biochemical parameters (carbohydrates and proteins) so obtained from the present studies shown in table no. 4 were also noted to be one of the main factors to contribute to the preference of the rice weevils in which rubber milled rice (having $55.55 \pm 0.67 \%$ and 11.05 $\pm 0.15 \%$ carbohydrate and protein respectively) had greater quantity of these as compared to the iron milled rice (49.74 \pm $0.67 \%$ and $9.09 \pm 0.15 \%$ carbohydrate and protein respectively). Among all other biochemical constituents, carbohydrate is the main factor which the weevil prefers. Preference of rice weevil towards the rice grains produced from rice/palm husker may be due to the less or no injury to the bran or germ of the rice grains. Germ is the most nutritious part of the grain and obviously the rice weevil feeds on it which was also supported by Howell and Cogburn (2004) by stating that after hatching, larvae begin feeding on the endosperm or germ. In case of iron milled rice grains, the infestation was lower and carbohydrate $\%$ and protein $\%$ were also present in lesser amount.

This may be due to the mechanical injury inflicted during the process of milling whereby the bran and/or germ of the rice grains were damaged more or might be that those were totally removed rendering the grains less preferred. These findings are supported by many authors namely McGaughey, (1974), Cho et al., (1988), Lucas and Riudavets, (2000), Haryadi and FleuratLessard, (1994) and Riudavets and Lucas, (2000) who observed that the polishing process had a negative impact on rice weevils because of the mechanical action of the milling process which damaged the grains and made the rice grains to white rice by removing the germ and bran of the rice grains with low nutritional quality. Further Lucas and Riudavets, (2002) also lends support by reporting that polishing process itself and the effect of reduced rice quality, had a significant impact on weevil density. So far the literature accessed there is no information with regard to the studies on the effect of milling methods on the grain weight loss, damaged grain percentage, population of the rice weevils in rice. It is also evident from the results given in table no. 1,2 and 3 that the grain weight loss, damaged grain percent and the population was always greater in summer as compared with winter in all the rice categories in both the years of studies.

\section{References}

Arbogast, R T., (1991) Beetles: Coleoptera. In: Gorham, J.R. (Ed.), Ecology and Management of Food-Industry Pests.Food and Drug Administration Technical Bulletin 
4: 131-176.

Beckett, S J, Longstaff B C, Evans D E (1994) A comparison of the demography of four major stored grain coleopteran pest species and its implications for pest management 491-497.

Cho K J, Ryoo M I, Kim S Y (1988) Life table statistics of the rice weevil (Coleoptera: Curculionidae) in relation to the preference for rough, brown and polished rice. Korean Journal of Entomology 18: 1-6.

Floyd E H and Newsom L D (1959) Biological study of the rice weevil complex. Annals of the Entomologicl Society of America 52: 687-695.

Food and Agricultural Organization of the United Nations (1954) F.A.O Nutritional Studies No. 1, revised. Rice and Rice Diets-A Nutritional Survey. F.A.O. Rome.

Haryadi Y, Fleurat-Lessard F (1994) Factors affecting survival and development of Sitophilus oryzae (L.) in rice grain pericarp layers. In: Highley, E., Wright, E.J., Banks, H.J., Champ, B.R. (Eds.), Proceedings of the Sixth International Working Conference on Stored-Products Protection. CAB International, Wallingford, United Kingdom, pp. 525-527.

Howell T A and Cogburn R R (2004) Rice Chemistry and Technology. In: Rough Rice Storage, American Association of Cereal Chemists, St. Paul, 269-283.

Jones J W, Zeleny L and Taylor J W (1946) Effect of Parboiling and Related Treatments on the Milling, Nutritional, and Cooking Quality of Rice. U.S.D.A. Cir. No. 752.

Juliano B O, G W Bautista, Lugay J C and Reyes A C (1964) Studies on the Physicochemical Properties of Rice. J. Agr. Food Chem. 12:131-138.

Lucas E, Riudavets J (2000) Lethal and sublethal effects of rice polishing process on Sitophilus oryzae (Coleoptera:
Curculionidae). Journal of Economic Entomology 93: 1842-1847.

Lucas E, Riudavets J (2002). Journal of Stored Products Research 38:293-304.

McGaughey W H (1974) Insect development in milled rice: effect of variety, degree of milling, parboiling and split kernels. Journal of Stored Products Research 10: 81-88.

Oko A O, Ubi B E, Efisue A A and Dambaba N (2012) Comparative Analysis of the Chemical Nutrient Composition of Selected Local and Newly Introduced Rice Varieties Grown in Ebonyi State of Nigeria. International Journal of Agriculture and Forestry 2(2): 16-23.

Poonam Dhankhar (2004). Rice Milling M.Tech (Food tech), G.J .U.S \& T, Hissar IOSR Journal of Engineering (IOSRJEN) ISSN (e): 2250-3021, ISSN (p): 2278-8719 Vol. 04, Issue 05 (May. 2014), ||V4\| PP 34-42.

Riudavets J, Lucas E (2000) Biological control of Sitophilus oryzae (Coleoptera: Curculionidae) and combined effect with polishing process. O.I.B.C./W.P.R.S. Bulletin 23: 143-148.

Russell M P (1968) Influence of rice varieties on oviposition and development of rice weevil Sitophilus oryzae Linn. and the maize weevil Sitophilus zeamais Linn. Ann. Entomol. Soc. Am. 61: 1335-1336.

Schramm, Rebecca C., "Rice processing: milling and value-added effects" (2006). LSU Master's Theses. 887. https://digitalcommons.1su.edu/gradschool_t heses/887.

Stejskal V and Kucerova Z (1996) The effect of grain size on the biology of Sitophilus granarius (L.) (Coleoptera: Curculionidae). I. Oviposition, distribution of eggs and adult emergence. J. Appl. Entomol 120: 143- 146.

\section{How to cite this article:}

Supriya Okram and Hath, T. K. 2020. Effect of Milling Methods on the Infestation of Sitophilus oryzae (L.) (Coleoptera: Curculionidae) on Stored Rice Grains in Terai AgroEcology of West Bengal. Int.J.Curr.Microbiol.App.Sci. 9(08): 880-886.

doi: https://doi.org/10.20546/ijcmas.2020.908.095 